\title{
REVIEW
}

\section{From Beyond the Grave}

\section{The Life and Death of the Avant-Garde}

Mikkel Bolt: Avantgardens selvmord. Copenhagen: 28/6, 2009. 109 pp. I S B N 978-87-92529-03-9

In April 1981, at the University of Iowa, American poet David Antin performed one of his "talk poems," a genre that he had developed during the preceding decade, as the malicious political rhetoric and double-talk in the US during the Vietnam War had forced him to reconsider established forms of poetry. The title of the piece that he read in Iowa this spring day was called "what it means to be avant-garde," named to fit the context of the talk, which was a conference on the avant-garde. ${ }^{1}$

However, since these talk poems are improvised by Antin on stage, with the common provisos on improvisation, such as mental planning and the employment of topoi, the outcome of the piece was not predictable in advance.

As usual the talk began with an anecdote. This time it was about Antin reading an article in a newspaper on the plane to Iowa, an article discussing the plans of Bulgarian artist Christo to cover ten islands in the Biscayne Bay outside of Miami in pink fabric, and the debate that had ensued in the local community. From this starting point the talk meandered on, incorporating and reflecting upon the key concept of the event in relation to a variety of contexts ("i'm not proposing christo as an avantgarde artist") while at one point, about a third into the piece, reaching something of a defining moment in relation to the title. Tongue-in-cheek paraphrasing the woes of some speakers on the conference - their longing for a revolutionary past, while white ducks crossed the sundrenched lawn of the campus after a storm - Antin wondered if the reason why he saw himself as such a "poor avant-gardist" was that he was not prone to lament the decline of past deeds, but that he wanted to "occupy the present $[. .$.$] which if i can find it might let me know what to do".$

Antin's ambition, as stated and performed in his talk poems, comes forth as rather small-scale and humble in the light of the heroic gestures and claims connected to the historical avant-garde of the early 20 th century. Still, his practice is very much in sync with the performative 
aesthetics and politics explored by former "avant-gardists" through the genre of the manifesto or through the employment of the stage as a setting for artistic action. But instead of taking the opportunity to dramatize a specific program and address the future, Antin had cut down his radius of action to the context-bound and the local, to the embodied here and now, while also, through improvisation and interaction with the audience, allowing for the indeterminate to become part of his work. Even though the succeeding passage in "what it means to be avant-garde" segues into a brief discussion of the political situation in the US at the time, the emergence of Reaganomics and its effects on everyday life, Antin's avant-garde intervention, supposing that is a fitting name for it, is more modest. And it does, in many ways, seem emblematic of the tactical and micropolitical work of the so-called neo-avant-garde that took shape during the decades after World War II.

It is difficult not to recollect such moments from the last decades in art while traversing the text of Mikkel Bolt's recent Avantgardens selvmord (The Suicide of the Avant-Garde); a book - essay, cultural intervention, and potential debate-cooker - whose aim is to outline the historical avant-garde's road to extinction and to ponder on the loss of grander political ambitions in innovative art today. ${ }^{2}$ It is a sombre and melancholy analysis of the situation that Bolt conjures up. And even though the essay's conclusion seems to offer an active choice between war and revolution, the ending is set in a minor key, where late capitalism, or, rather, a "militarized global capitalism" (102) - formed already in the 1970 s and reinforced by a post-9/11 control regimentality embellished as war on terrorism - reigns.

For sure, Bolt discerns, here and there, pockets of resistance, identified and discussed through the lens of some of the important political thinkers and philosophers of the day, such as Giorgio Agamben, Alain Badiou, and Jacques Rancière. But these particular political movements designated as "identity politics" - cannot be compared to the attempts of a historical avant-garde to both collaborate with actual political parties of the left (and sometimes right) and to explain "how society functions or can be transformed" (103). The radical project of making art coalesce with life or, rather, to change life and society in its totality, is lost. The - or that, to be more cautious - avant-garde is dead, Bolt concedes, echoing a bunch of thinkers from the last century. It has even, as the title suggests, committed suicide.

This might seem like an ominous observation - a diagnosis that does not leave much room for hope. Or does it, on the contrary, open up the 
possibility for a remedy, for correcting some fundamental mistake made on the way from Dada and surrealism to the present state of innovative art and politics? Well, that question haunts Bolt's essay, even though no particular answer or solution is offered. What is more striking, though, is perhaps the apparent untimeliness of Bolt's stance in his book. In a time period when reflection on the avant-garde as a historical phenomenon and as an archive to be re-organized and re-used by academics, critics, and artists, has been flourishing for some time, Bolt returns, more or less, to a position outlined by Peter Bürger in his Theory of the Avant-Garde thirty-five years ago, and further developed by critics such as Andreas Huyssen. ${ }^{3}$ Even though Bolt by no means wants to overtake Bürger's simplified view of the postwar avant-garde (minimalism, concrete poetry, happenings, serial music, and so on), the net outcome of his discussion is that the avant-garde proper was to be found during the first part of the twentieth century, with the eminent exception of the International situationniste. And this position, among other things, makes it interesting to take a closer look on what the suicide of the avant-garde is all about.

Mikkel Bolt is a specialist in the avant-garde of the previous century (he is associate professor at the University of Copenhagen), and is known as a versatile critic of culture and politics during late capitalism. He has published extensively on the French situationists, but also on contemporary philosophy and experimental art. In Avantgardens selvmord, however, the aim is not so much to analyze and map out the avantgardes of the 2oth century in their various forms, in their multitude and complex networks, as it is to circumscribe a specific field of action and practice, and from this vantage point offer a story of rise and decline. Bolt makes it clear from the start that his conception of the avant-garde is distinct from the contemporary research hinted at above, which has tended, according to him, to neglect the "revolutionary aspirations of the avant-garde" as a fundamental component of its "self-understanding" (8). As Bolt states, his essay comes forth as a series of remarks - triggered by his research of the situationists - where he tries to incorporate this selfunderstanding into a reflection of the avant-garde's disappearance. The book can thus be considered, as he writes, both as a form of escape "out of the occupying universe of the avant-garde and as an attempt to keep the energy of the avant-garde alive, in spite" (9).

Avantgardens selvmord is organized in four chapters, dealing with, respectively: the ambition to change life and society as a totality within the twentieth century avant-garde; the secret group and activities around the French journal Acéphale by the end of the 1930s; the Internationale 
situationniste, inaugurated, developed, and dissolved by Guy Debord; and, finally, the current global political situation and the potential of an avant-garde response to this situation. The first chapter is, of course, the place where demarcation lines are drawn, and where crucial observations and negotiations are made. While beginning with a discussion of the negativity of the avant-garde, its making strange of the images and narratives that bourgeoisie society fed itself on in the early 2oth century, Bolt soon develops an argument of why such an intervention into a dominant culture is no longer pertinent, or even possible, during the second half of the century, while at the same time brushing aside the thought of designating certain contemporary artistic practices - Das Beckwerk, Luther Blissett, and Wu Ming are mentioned - as avantgarde in a rigorous sense.

Here Bolt, then, initiates his return to the work of Peter Bürger, whose theory comes out as more valid than it has for a while. Even though Bolt, as mentioned, distances himself from Bürger's problematic understanding of the neo-avant-garde, he still considers it important to make a clear distinction between Futurism, Dada, surrealism, constructivism, on the one hand, and such potential avant-garde's movements or practices as minimalism, Fluxus, or conceptual art, on the other. The distinction is motivated by the thorough historical transformation that took place during the fifty years in between. Recapitulating observations by Bürger, Bolt contends that the early avant-garde combination of a radical critique and a utopian politics are no longer conceivable. The hegemonic culture industry (or, let us be pre-emptive, the spectacle) absorbs every attempt at construing an outside from which to deliver such a critique of society, and those instruments that were once available for avant-garde de-familiarization of bourgeoisie complacency, such as technology, have become a naturalized part of everyday life. As Bolt writes: "Wherever artists acted, their works and deeds were, after 1945, destined to commercial integration or institutional incorporation, one way or the other" (16).

Thus innovative art in the postwar period, such as the conceptual work of Art \& Language, though no doubt politically charged and informed by Marxist ideas, could not, according to Bolt, reach the same degree of radicality as was the case in the beginning of the century. Its political potential can only be piecemeal, and, thus, one must conclude, not productive enough. There is, however, an eminent exception to this scheme - the Situationist International, whose practice will serve as more than an object of analysis for Bolt. It is actually Guy Debord, and, more specifically, a discussion between Debord and French sociologist 
Robert Estival in the early 1960s, that lays the ground for Bolt's decision to make the avant-garde's self-understanding his own. As Debord claims in his attack on Estival: a ceding to the perspective of the insider is the only way of truly understanding the avant-garde. Every analysis at a distance will hypostasize the negative dialectics at play in its activities. The "avantgarde is not," Bolt underlines, "the designation of a determined positivity" - "only by constant projection can the avant-garde make itself a place. It must all the time represent itself, and avoid others' representations of it. Therefore the avant-garde is never positive, it is negative in a blank and paranoid way" (28-29).

From such a viewpoint, it is easy to see how the series of attempts of the early avant-garde to collaborate with established political parties were doomed to fail from the start. Still they tried, in their search for a social body to supplement the elitist head that they themselves constituted (to use the metaphors employed in the essay). The main example brought up by Bolt in this context is the surrealists' negotiations with the French communist party during the interwar period, which came to a halt in 1935, when Stalin signed a non-aggression pact with the French government, and thus betrayed the internationalist ideas underpinning communism.

In light of such failures, the second chapter of Avantgardens selvmord turns instead to one of the most secluded and mythic avant-gardes in France from the last century; a group initiated by French writer and philosopher Georges Bataille during the last years of the 1930s, and whose activities were linked to the journal with the same name, Acéphale, or "headless," carrying the famous emblem, by artist André Masson, of a decapitated man with a sword in one hand and a flaming heart in the other. The activities of Acéphale were indebted to the early philosophy of Bataille, who had been part of the surrealist movement, but who was soon to part ways with Breton and his peers. Bataille himself rejected, as Bolt reminds us of, a surrealist ideology that he considered too humanist and "edifying," and navigated instead towards an experience of irredeemable loss, excess, and waste. What exactly the activities of Acéphale came to consist of remains obscure. Even though sacrifice, even human sacrifice, seems to have been part of the program, no coherent and convincing testimony of what took place at the group's gatherings in the forest SaintNom-la-Bretèche is available. But this "unawareness is exemplary for the nature of the project," Bolt writes, "it was about getting away, of becoming invisible, of giving oneself up to the sacred" (41).

In this endeavour, Acéphale took to heart the avant-garde idea of transforming not only art, but life as such. The production of writing and 
images - representations - was not enough. So-called reality had to be engaged in the group's acts of transgression. Bolt follows Bataille's intensive search for such a transgressive experience beyond the utilitarian confines of capitalism, liberalism and Marxism, and his attempt at finding support for his project of the sacred and ecstatic in fascism, whose capacity to mobilize the masses, to resurrect myth, and so on, made an impression on Bataille, even though he soon discovered that these forces were released only to be recuperated by the very bourgeois mechanisms that were threatened to begin with. The interminable subversion that Bataille sought for could not be found here.

The only way out seemed to be through a return to religion, or, rather, through the establishment of a new kind of religion. In order to avoid the lure of the useful and the calculable, such a religion would be forced to turn its destructive energies toward itself. Here was a path away from instrumental thinking and prudish reason, toward freedom and nonrefundable excess. This meant that self-inflicted death, in the end, became a search for treasure. "Acéphale was dedicated to this death" (63) and, accordingly, to its own dissolution. This became the core of their ecstatic community, and in the "apocalyptic laughter" they wanted to release in lieu of a traditional political program. That this venture, as well as the general economy outlined by Bataille after World War II, entailed a number of inner contradictions and paradoxes, that it could not escape from the utilitarian logic so detested by Bataille, was, of course, to be shown later by Derrida and others. It was an impossible project, a project of the impossible, in more ways than one.

After discussing the attempt to link the negativity of the early avantgarde to party politics, and the almost opposite attempt of turning critique into a practice of ecstatic self-sacrifice and destruction, Bolt returns in the third chapter of his book to the figurehead in his story of the avantgarde, Guy Debord. He does not pay much attention to the (semi-)artistic strategies developed by the situationists during the last years of the 1950s, such as the dérive and the détournement. It is the more pronounced political analysis taking shape in the 1960s, culminating in Debord's The Society of the Spectacle (1967), that is brought to the fore - an analysis that partly converges with the position of Bürger and, to some extent, with the one occupied by Adorno and Horkheimer in their analysis of the culture industry. And here one will also find a reason why a postwar avant-garde, such as the situationists, cannot be satisfied with operating within the sphere of art. "It was, according to the situationists, no longer possible for art," writes Bolt, "to critically appropriate the images of the 
spectacle. Art had itself become part of this alienating image regime that was to be destroyed" (71). At the most, a postwar movement such as Pop art could stage a kind of "meta-spectacle," which would not, however, affect the regulating machinery of society. Nothing less than the "sublation of art and the routines of everyday life could be the goal for the contemporary avant-garde" (72).

This goal of transforming everyday life, its framing conditions and its potentials, is discussed by Bolt in close contact with situationist manifestos and essays. First, the history that brought forth the conditions of the postwar decades is outlined. By mid-century, the technological development of modernity had made it possible for people to change their lives, especially with regard to work and leisure, but the social institutions and structures lagged behind and prevented such a change - "the social order blocked this development and had created a gigantic system of representations, whose function was to shut out the demand for another organization of society" (74). This regime of images, the spectacle, did not only exclude the potential for play and other activities outside the machinery of market capitalism. It also concealed class differences and class struggles as well as the very conceptualization of a life beyond stories and emotions conjured up by capitalism.

Bolt observes how close the situationist analysis of the spectacle is to Marx, and to his conception of religion, even though the spectacle is much more total in its reach - it filters all communication and every social relation as Debord underlines early on in The Society of the Spectacle. Still, in order to come forth as an avant-garde in the sense evoked by Bolt in his essay - as a movement that tries not only to understand but also to criticize and change life and society in its totality - there must be a way out of this all-encompassing regime of representations. Or, mustn't there? Here one encounters what might look like the situationist's impossible, the aporia of their theory: If the spectacle covers everything, how then to change things or even deliver a credible critique of a numbing status quo?

There was a theoretical solution at hand, which Bolt touches upon, in establishing the proletariat as a trans-historical agent for a continuous critique. But, in practice, this Gordian knot between reality and spectacle was loosened, and the seemingly inevitable disillusion dispersed. Apart from continuing their attack against late capitalism in numerous manifestos - a performative genre briefly discussed by Bolt with the help of avant-garde scholar Janet Lyons, among others - Debord and his compatriots would postulate their own revolutionary project, the construction of situations, as 
a viable intervention and as a counter-image to the alienating representations of the spectacle. Through these constructions life as such could or, rather, must be changed. But exactly how this change was to come about is not perfectly clear. As Bolt writes, there is something "pathetic" in the analysis (but also in the attack, I would add) staged by the situationists. And perhaps, at least this is Bolt's suggestion, something "grand and intoxicating" (95).

As described in the beginning of this article, the last chapter of Avantgardens selvmord, then, takes place on the day after such intoxicating experiences. By no coincidence, the main part of the chapter is titled "Ruins" - a perfect setting, of course, for dreary ruminations. However, when wandering through the political remains of things past and present one cannot refrain from asking to what extent such a gloomy mood is motivated in dealing with the avant-garde - specifically - today? That the contemporary global political situation offers reasons to gloominess as well as anger is indubitable. But what does this have to do with the avant-garde, and with aesthetic-political practices in its wake during the 1960 or 1970 s or today? And what "avant-garde" are we talking about should we talk about - anyway?

I guess my first concern with Bolt's essay takes shape in the vicinity of his conception and definition of the avant-garde and the ensuing view of the discourse on the topic during the last two decades. His contention that recent research, post-Hal Foster, and Foster's critique of Bürger, ${ }^{4}$ has failed to consider the revolutionary ambition and pathos of the avant-garde is, even if probably true in several cases, too reductive as a characterization of the whole multifarious field. Secondly, such a characterization immediately raises the question whether the implicated or entailing conception of the avant-garde is a pertinent and productive one. Even though grand revolutionary ambitions were an important part of the early avant-gardes' self-understanding, is this enough to consider it, even turning it into a defining criterion of a potential tradition as such? Is the idea of changing life and society in its totality, which becomes operative in Bolt's essay, really a necessary adjunct in the search for what can be considered as avant-garde?

If such a view facilitates the autopsy, it also tends to blur the contours of the work by a number of artists and movements during the second half of the 2oth century, which would more or less actively re-connect with and re-format the operations and attitudes of Futurism, Dada, surrealism, and so on, in ways that at least forces one to consider the possibility of them being avant-garde, without having to approach them as 
zombies. Admittedly, there are no clear-cut and easily applicable definitions out there, and there will never be. But there are reasons to embrace a more flexible and open notion of the avant-garde such as, for example: a formally innovative politically charged aesthetic activity that entails an exploration and, perhaps, a challenge to the established institutional and societal conditions for artistic practice. This is not meant as a serious definition, but only a way of pointing to an exit that Bolt in his essay would not acknowledge as more than a fake door out of the closed room, the sepulchre, that his avant-garde ends up in.

Why, then, would this be a better option? First of all, let me make it clear that I see no reason, and I doubt anyone would be interested in it, to restore the concept as a usable ID-card among artists and writers today and yesterday. And as such it has rarely been used. No, but the concept opens a space for mapping out and analyzing certain aesthetic and political activities from the last hundred years (approximately). And in that sense it can certainly be processed in dealing with a wide range of later artistic practices, from musique concrète and minimalism to conceptual poetry and ventures such as Das Beckwerk today.

One cannot find, in the work of Haroldo de Campos, Sol Lewitt, David Antin, or Öyvind Fahlström - or even of John Cage, Joseph Beuys, Art \& Language, or Victor Burgin - the same kind of revolutionary politics as in the surrealist movement. And Bolt, with Bürger and others, gives an explanation as to why. However, the work of these artists certainly carries a multifaceted radical political charge, and one more attuned, perhaps, to the changed conditions for artistic production under late capitalism. One does not even have to agree with Hal Foster that the institutional critique in Dada and Duchamp, celebrated by Bürger, will not take effect until it is repeated with the postwar neo-avant-garde. One might just as well be bluntly empirical, and point, for example, to the amalgamation of feminist art and politics staged in performances by Carolee Schneeman, Lygia Clark, Yvonne Rainer and others during the 1960s, followed by a heterogeneous body of activities in the 1970s (from Eleanor Antin to Martha Rosler to Jenny Holzer to Laurie Anderson), to find a practice that could qualify as avant-garde for a number of reasons - such as formal innovation, generic and medial hybridity, the critique of the artist genius, institutional critique in general, a questioning of the border between art and life praxis, and so on. ${ }^{5}$

Now, Bolt is, of course, aware of all this. But still, he looks for a more thorough confrontation with society as a totality. The piecemeal and tactical politics, a politics from within societal structures, from within the 
spectacle, cannot be considered as avant-garde according to such a stipulation. It is thus, it seems, a narrower view of politics that is at play - that is deemed as relevant and necessary, in light of a contemporary situation - in Avantgardens selvmord. As a consequence, a politics of poetic form, for example such as the one outlined in North-American language-poetry, would not fit into this scheme of things avant-garde.

This brings me to a second concern with Bolt's essay, which might be posed as a question: Is not a negligence, similar to the one he accuses some contemporary research of the avant-garde of showing, manifested in his own reflections? That is: What becomes of aesthetics, of the aesthetic operations and strategies of early and later avant-gardes? True, names of artists and writers circulate in the essay, and Bolt mentions the existence of formal experiments, and so on. But there are no fuller discussions of artworks (in a wide sense) in Avantgardens selvmord. One could perhaps inject that politics is what is at stake here. But can the two really be separated? Is it not the combination of the two that makes the whole project, the whole conceptual and phenomenal complex feasible to begin with?

It is tempting to bring up one aspects of Foster's critique of Bürger here, that even though the latter offers a keen (and brilliant, especially in being among the first ones offered) analysis of the institutional critique in Dada and Duchamp, he also blinds himself to the aesthetic dimensions of the readymade, for example. And it is tempting to bring up the reminder that it was the appropriation and transformation of aesthetic operations, such as the readymade, performance, sound poetry, collage, montage, and so on - in conjunction with an awareness of the institutional conditions and the political potentials of artistic practice - that made it possible to discern a neo-avant-garde in the first place, and the existence of an avant-garde tradition (a term that should perhaps be used under erasure) that lingers on, potentially, in our own time.

Once again, objections such as these tend to be or at least feel slightly oblique, considering the errand of Avantgardens selvmord - to recapture some of the lost energy of a revolutionary avant-garde politics, in spite of its aporias. Still, such an errand comes at the price of exclusionary maneuvers. Further, the literary historian at my shoulder is not altogether convinced of the productivity, the wisdom, the advisability of letting the avant-garde's, or rather Guy Debord's and the situationists', self-understanding play such a central role in this endeavour.

There are also some minor moves in the argument of Bolt's book that has left me wondering. Let me just mention the claim on page 26 that 
the subjectivation mode of the avant-garde always takes shape through orders or commands. This seems problematic to reconcile with (if I understand Bolt's intentions correctly) the playful dissolution of subjective agency (individual or collective) at work in Dada performances or nonsenselike sound poetry, for example. That said, I must also underline that I find it very hard not to be smitten by the initiative of Bolt's book (which is, of course, theoretically and historically well-informed). The essay comes forth as an energetic appeal from a historical situation that, understandably, calls for action, and that it loses some of its initial intensity in the darker pages that end the book, as the impasses of the old avant-garde have been outlined and confirmed, is understandable.

It is, after all, an essay "in spite." And as such it is recommendable to anyone engaged in the history (and future) of the avant-garde. The stronger claims and the cleaning out of the field that is performed, as well as the return to Bürger (and Debord) forces the reader to reflection and reconsideration. Even if I am reluctant to agree with the idea of what it means to be avant-garde that his essay implies, even if I prefer to leave the possibility open of inserting the micropolitical talks of a David Antin into a historical network of avant-garde activities, I will continue to ponder on his appeal for some time.

JESPER OLSSON

\section{Notes}

1. See David Antin, what it means to be avant-garde (New York: New Directions, 1993), 40-61.

2. Avantgardens selvmord (Copenhagen: Forlaget 28/6, 2009). All translations from Bolt's book are mine.

3. See Peter Bürger, Theorie der Avant-Garde (Frankfurt am Main: Suhrkamp Verlag, 1974) and Andreas Huyssen, After the Great Divide (Indiana: Bloomington University Press, 1986). As for the recent discussion of an avant-garde tradition, one might refer here, as Bolt does, to a publication such as En tradition af opbrud: Avantgardenes tradition og politik, ed. Tania Ørum, Marianne Ping Huang and Charlotte Engberg (Hellerup: Forlaget Spring, 2005), which gives a fine overview of the contemporary research on a tradition of the avant-garde.

4. In Hal Foster, "Who's Afraid of the Neo-Avant-Garde," in The Return of the Real (Cambridge: MIT Press, 1996).

5. Cf. Henry. M. Sayre's critique of Bürger in the light of feminist art of the 1960 s and 1970s in The Object of Performance: The American Avant-Garde since 1970 (Chicago: University of Chicago Press, 1989). 